\title{
The Quality of Life Level in Female Patients with Fibromyalgia Syndrome and the Associated Factors
}

\author{
Fibromiyalji Sendromlu Kadın Hastalarda Yaşam Kalitesi Düzeyi ve Iliş̧kili Faktörler \\ (D) Aliye Bulut, (D) Emel Top \\ Bingöl University Faculty of Health Sciences, Department of Nursing, Bingöl, Turkey
}

\section{Abstract}

Objective: In our study, we were examined the quality of life and its relationship with socio-demographic characteristics in female patients with Fibromyalgia syndrome (FMS) who applied to outpatient clinic.

Materials and Methods: In the study, 108 female patients applying to physical therapy outpatient clinic between May 1, 2017 and September 1, 2017, and diagnosed with FMS were included. The data collection tool used in the study was the questionnaire developed by the researcher based on the literature information. The questionnaire consisted of two parts. The first part of the form consisted of the question set querying the socio-demographic characteristics (15 questions), and the second part consisted of the quality of life bref scale used to assess the quality of life of the cases.

Results: When the quality of life scores of the individuals according to their economic status were examined; the emotional role functioning, physical functioning, physical role functioning, and physical indicator scores of individuals with middle income level were significantly higher than other income groups $(p<0.05)$.

Conclusion: Consequently, we can say that the quality of life is better in female patients who have a high income level with education, normal body mass index, regular sleeping and diagnosis of fibromyalgia.

Keywords: Fibromyalgia, quality of life, clinical characteristics

\section{$\ddot{O z}$}

Amaç: Çalışmamızda, polikliniğe başvuran Fibromiyalji sendromlu (FMS) kadın hastalarımızda yaşam kalitesini ve yaşam kalitesinin sosyodemografik özellikler ile ilişkisini inceledik.

Gereç ve Yöntem: Çalışmada, 1 Mayıs 2017 - 1 Eylül 2017 tarihleri arasında fizik tedavi polikliniğine başvuran ve FMS tanısı alan 108 kadın hasta alındı. Araştırmada kullanılan veri toplama aracı literatür bilgilerine dayanarak araştırmacı tarafından geliştirilen anket formudur. Anket formu, iki bölümden oluşmaktadır. Formun birinci bölümü sosyo-demografik özellikleri sorgulayan soru takımından (15 soru), ikinci bölümü ise, olguların yaşam kalitesini değerlendirmek için kullanılan yaşam kalitesi kısa ölçeğinden oluşmuştur.

Bulgular: Bireylerin ekonomik durumlarına göre yaşam kalitesi puanları incelendiğinde; orta gelir düzeyine sahip olan bireylerin emosyonel rol güçlüğü, fiziksel fonksiyon, fiziksel rol güçlüğü ve fiziksel göstergeler skorları diğer gelir gruplarına göre anlamlı derecede yüksektir $(p<0,05)$. Sonuç: Sonuç olarak; eğitim ile gelir düzeyi yüksek olan ve beden kitle indeksi normal olup, düzenli uyuyan fibromiyalji tanısı alan kadın hastalarda yaşam kalitesinin daha iyi olduğunu söyleyebiliriz.

Anahtar kelimeler: Fibromyalji, yaşam kalitesi, klinik özellikler

\section{Introduction}

Fibromyalgia is a disease characterized by widespread chronic musculoskeletal pain. Peripheral and central pain mechanisms are thought to have a role in genetic basis at fibromyalgia etiopathogenesis (1). The etiology and mechanisms of Fibromyalgia syndrome (FMS) are not exactly understood, however, central pain mechanisms and central sensitization as well as neuroendocrine dysfunctions are the most important factors in the development of FMS (2). Fibromyalgia affects $1-2 \%$ of the community and most of them are female patients aged between $40-55$ years $(3,4)$. The quality of life briefly defines "how the person perceives his/her own health subjectively in the environment he/she is in". This concept is not a quantity measured by medical techniques and laboratory processes, but it is a quality experienced subjectively. The quality of life is multidimensional and the criteria used are affected by the disease itself and its severity. The quality of

Address for Correspondence/Yazıșma Adresi: Aliye Bulut MD, Bingöl University Faculty of Health Sciences, Department of Nursing, Bingöl, Turkey Phone: +90 5058173113 E-mail: aliyedemirok@yahoo.com ORCID ID: orcid.org/0000-0002-4326-0000 Received/Geliş Tarihi: 22.02.2018 Accepted/Kabul Tarihi: 09.07.2018 
life is an important measure in the effect, treatment and follow-up process of the chronic diseases such as rheumatic disease on a person. One of these diseases is FMS (5). FMS disturbs the physical and emotional quality of life by causing significant difficulties in the person's functional capacity and activities of daily living. For this reason, the quality of life scales are often used. The scales developed to measure quality of life include physical and occupational functions, social interaction, psychological and economic conditions. Numerous scales used for this purpose are involved in the literature and among them the scale which is most frequently used in the health researches is "the quality of life scale" which has 36 questions and 8 subscales short form-36 (SF-36) (6). Being widely used in Turkey and in the world in order to measure the quality of life, the SF-36 evaluates the health status with its positive and negative aspects. The high scale score signifies a good quality of life (7). Determining the factors affecting the quality of life in FMS seems important at the stage of directing the treatment of the disease. In the present study, the quality of life of female patients with FMS applying to outpatient clinic and the correlation between the quality of life and socio-demographic characteristics were examined.

\section{Materials and Methods}

Necessary written permissions were obtained from related institutions before the study. A total of 108 female patients who applied to the Bingöl State Hospital Physical Medicine and Rehabilitation outpatient clinic that diagnosed of FMS according to 1990 American College of Rheumatology FMS classification criteria and filled out of informed voluntary consent were included in this study. The study was performed in accordance with the principles of Declaration of Helsinki. The ethical approvals were taken from Bingöl University Scientific Research Publications Ethics Committee (dated 09.05.2016 and numbered 29). All participants gave written and verbal permission to participate in this study. The sample of the study consisted of the patients who were followed-up with the diagnosis of FMS, were able to communicate and were voluntary to participate in the study. Patients whose complete blood count, complete urine test, sedimentation rate and serological tests (Syphilis, Brucella, Hepatitis markers, human immunodeficiency virus) were in the normal limits and who had no significant systemic disease were included in the study. In addition, attention was paid so that all the cases included in the study had no additional disease like systemic and inflammatory diseases. The data collection tool used in the study was the Questionnaire developed by the researcher based on the literature information. The questionnaire consisted of two parts. While the first part of the questionnaire consisted of a question set checking the socio-demographic characteristics (15 questions), the second part was the quality of life scale (SF-36) used for evaluating the quality of life of the cases. It is a widely used quality of life measure and has high reliability (8). It is not only intended for a single disease but also it can be used for all chronic diseases. Therefore, in the present study investigating the female patient group with FMS, the use of SF-36 was preferred in evaluating the quality of lives of the patients.

\section{Statistical Analysis}

The data were prepared for analysis on SPSS, Version 22.0 following export from Qualtrics. Mean scores were given with standard deviation and the value of $p<0.05$ was determined as significance level. Frequency was benefited in presentation of the descriptive data, while Kruskal-Wallis Variance analysis from nonparametric hypothesis tests used to compare more than two groups was used in the evaluation of statistical significance of the other data.

\section{Results}

Table 1 shows the general characteristics of the individuals participating in the study. The majority of the individuals were illiterate $(28.7 \%)$, had a middle income level (75.9\%), and were mostly housewives (49.1\%). $45.4 \%$ of the individuals did not smoke and reported the disease as the event affecting their life $(24.1 \%)$. In addition, it was also found that $76.4 \%$ of them had irregular sleep and $60.2 \%$ had no illness. When the status of having a psychological disease was examined, $86.1 \%$ of them were observed to have no disease. A great majority of the patients received physical therapy (43.5\%) and physical therapy+medication together (39.8\%). Table 2 shows the distribution of scores of the life quality according to educational status. According to this, all the quality of life components other than general health were higher in the individuals whose educational level was university than individuals in the other educational levels and it was statistically significant $(p<0.05)$. The general health component was significantly lower in illiterate individuals than other groups $(p<0.05)$; this score of the other groups was close to each other.

When the quality of life scores of the individuals according to their economic status were examined (Table 3); the emotional role functioning, physical functioning, physical role functioning, and physical sign scores of individuals with middle income were significantly higher than other income groups $(p<0.05)$. The pain score was found to be higher in the individuals with high income than the other groups and it was statistically significant $(p<0.05)$. Table 4 shows the distribution of quality of life scores according to body mass index (BMI) groups. According to this, a significant difference in terms of BMl groups was seen only in the physical role functioning component $(p<0.05)$. Physical role functioning score of obese individuals was significantly lower than others. Table 5 shows the distribution of mean and standard deviation values of the quality of life scores according to the sleep pattern. While no significant correlation was found between the sleep pattern and physical signs except for physical role functioning score; whereas, the difference between the vitality and mental health from mental signs and total mental sign scores was significant. The physical role functioning score 
Table 1. Distribution of individuals in terms of their socio-demographic characteristics (\%)

\begin{tabular}{|l|l|l|}
\hline Characteristics & $\begin{array}{l}\text { Number } \\
(\mathrm{n})\end{array}$ & $\begin{array}{l}\text { Percentage } \\
(\%)\end{array}$ \\
\hline
\end{tabular}

\section{Educational status}

\begin{tabular}{|l|l|l|}
\hline Illiterate & 31 & 28.7 \\
\hline Primary school & 28 & 25.9 \\
\hline Secondary school & 18 & 16.7 \\
\hline High school & 9 & 8.3 \\
\hline University & 22 & 20.4
\end{tabular}

\section{Economic status}

\begin{tabular}{|l|l|l|}
\hline Low & 22 & 20.4 \\
\hline Middle & 82 & 75.9 \\
\hline High & 4 & 3.7 \\
\hline
\end{tabular}

\section{Profession}

\begin{tabular}{|l|l|l|}
\hline Housewife & 53 & 49.1 \\
\hline Worker & 6 & 5.6 \\
\hline Civil servant & 20 & 18.5 \\
\hline Student & 10 & 9.3 \\
\hline Retired & 6 & 5.6 \\
\hline Self-employed & 13 & 12.0 \\
\hline Smoking status & 49 & 45.4 \\
\hline Never & 34 & 31.5 \\
\hline Sometimes & 25 & 23.1 \\
\hline Addicted & &
\end{tabular}

Experiencing the event that will affect your life

\begin{tabular}{|l|l|l|}
\hline Death & 21 & 19.4 \\
\hline Accident & 5 & 4.6 \\
\hline Disease & 26 & 24.1 \\
\hline Economic difficulty & 7 & 6.5 \\
\hline Other & 23 & 21.3 \\
\hline Disease, economic difficulty & 8 & 7.4 \\
\hline Death, accident & 4 & 3.7 \\
\hline Accident, economic difficulty & 3 & 2.8 \\
\hline Death, economic difficulty & 4 & 3.7 \\
\hline Death, accident, disease & 5 & 4.6 \\
\hline Death, disease & 2 & 1.9 \\
\hline Sleep pattern & \multicolumn{2}{|l|}{} \\
\hline Regular & 11 & 10.2 \\
\hline Some nights & 14 & 13.0 \\
\hline Irregular & 83 & 76.9 \\
\hline Disease status & \multicolumn{2}{|l|}{} \\
\hline No & 65 & 60.2 \\
\hline Yes & 43 & 39.8 \\
\hline
\end{tabular}

\begin{tabular}{|c|c|c|}
\hline Characteristics & $\begin{array}{l}\text { Number } \\
\text { (n) }\end{array}$ & $\begin{array}{l}\text { Percentage } \\
\text { (\%) }\end{array}$ \\
\hline \multicolumn{3}{|l|}{ Disease name } \\
\hline Heart & 14 & 13.0 \\
\hline Diabetes & 2 & 1.9 \\
\hline Kidney & 2 & 1.9 \\
\hline $\begin{array}{l}\text { Waist, neck, joint and muscular } \\
\text { disease }\end{array}$ & 6 & 5.6 \\
\hline Heart, diabetes & 8 & 7.4 \\
\hline Digestive system & 4 & 3.7 \\
\hline Respiratory tract & 5 & 4.6 \\
\hline Celiac & 2 & 1.9 \\
\hline \multicolumn{3}{|c|}{ Status of having psychological disease } \\
\hline No & 93 & 86.1 \\
\hline Yes & 15 & 13.9 \\
\hline \multicolumn{3}{|l|}{ Patient } \\
\hline Mother & 22 & 20.4 \\
\hline Father & 2 & 1.9 \\
\hline My spouse & 17 & 15.7 \\
\hline Parents and siblings & 2 & 1.9 \\
\hline Mother father & 5 & 4.6 \\
\hline \multicolumn{3}{|l|}{ Treatment } \\
\hline Medication & 10 & 9.3 \\
\hline Physical therapy & 47 & 43.5 \\
\hline Other & 8 & 7.4 \\
\hline Physical therapy, medication & 43 & 39.8 \\
\hline $\begin{array}{l}\text { Duration of Fibromyalgia } \\
\text { disease (years) }\end{array}$ & \multicolumn{2}{|l|}{$3.5 \pm 3.2$} \\
\hline
\end{tabular}

was higher in individuals with regular sleep than the others and it was statistically significant $(p<0.05)$. While the mental health score was high in individuals sleeping irregularly at some nights; vitality score and mental signs score are significantly high in individuals sleeping regularly than the other groups $(p<0.0)$.

\section{Discussion}

All the quality of life components of the individuals, whose educational level was university, other than general health were higher than the individuals in the other educational levels and it was statistically significant $(p<0.05)$. The general health component was significantly low in the illiterate ones compared to the other groups $(p<0.05)$; this score of the other groups was close to each other. It was stated that FMS was seen more frequently especially in those who were female, had low educational level, and had low socio-economic level $(9,10)$. The effect of low educational level may be interpreted 
as not only being a stress factor but also affecting coping strategies, causing somatization to be used more by reducing the expression of emotions. When the quality of life scores of the individuals in terms of their economic levels were examined; emotional role functioning, physical function, physical role functioning and physical sign scores of the individuals with moderate income level were significantly higher than the other income groups $(p<0.05)$. The pain score on the other hand was higher in the individuals with high income compared to the other groups and this was statistically significant $(p<0.05)$. In a previous study, female gender, middle age, low educational level, low family income and being divorced in patients with fibromyalgia were reported to be the risk factors for Turkey (11). Lower educational levels, income levels, and future concerns may have caused adverse effects on the quality of life and psychological status of individuals. Giving nutrition training and performing the diet follow-up for individuals diagnosed with FMS and enabling them to acquire a physical activity habit gain importance (12). In a study conducted in the United States of America to determine the overweight and obese prevalence in female patients diagnosed with FMS, obesity prevalence of the patients diagnosed with FMS (61\%) was higher than the obesity prevalence (38\%) in the society (13). According to results of the present study; significant difference according to the BMI groups of the female patients participating in the study was only seen in the physical role functioning component $(p<0.05)$. Physical role functioning scores of the obese individuals were significantly low compared to the others. In the literature, it was determined that the quality of life in overweight and obese patients diagnosed with FMS was negatively affected

\section{Table 2. Distribution of mean and standard deviation values of quality of life scores according to educational status}

\begin{tabular}{|c|c|c|c|c|c|c|}
\hline \multirow{3}{*}{ SF-36 components } & \multicolumn{5}{|c|}{ Educational status } & \multirow{3}{*}{ p value } \\
\hline & \multirow{2}{*}{$\begin{array}{l}\text { Illiterate } \\
(n=31) \\
(x \pm S D)\end{array}$} & \multirow{2}{*}{$\begin{array}{l}\text { Primary school } \\
(n=28) \\
(x \pm S D)\end{array}$} & \multirow{2}{*}{$\begin{array}{l}\text { Secondary school } \\
(n=18)\end{array}$} & \multirow{2}{*}{$\begin{array}{l}\text { High school } \\
(n=9) \\
(x \pm S D)\end{array}$} & \multirow{2}{*}{$\begin{array}{l}\text { University } \\
(n=22)\end{array}$} & \\
\hline & & & & & & \\
\hline Mental signs & $28.7 \pm 15.9$ & $32.1 \pm 19.2$ & $31.2 \pm 11.1$ & $41.7 \pm 19.0$ & $53.5 \pm 17.1$ & 0.001 * \\
\hline Vitality & $29.7 \pm 14.3$ & $29.5 \pm 18.9$ & $38.1 \pm 9.1$ & $50.6 \pm 17.8$ & $50.5 \pm 19.1$ & 0.001 * \\
\hline Social role functioning & $29.0 \pm 21.3$ & $41.5 \pm 25.9$ & $37.5 \pm 26.8$ & $44.4 \pm 21.8$ & $54.5 \pm 27.4$ & $0.015^{*}$ \\
\hline Emotional role functioning & $14.0 \pm 26.9$ & $21.4 \pm 27.5$ & $0.0 \pm 0.0$ & $29.6 \pm 35.1$ & $54.5 \pm 40.6$ & 0.001 * \\
\hline Mental health & $42.1 \pm 24.1$ & $36.1 \pm 23.5$ & $49.3 \pm 15.9$ & $42.2 \pm 14.4$ & $54.5 \pm 15.9$ & $0.013^{*}$ \\
\hline Physical signs & $22.4 \pm 11.6$ & $36.4 \pm 20.7$ & $31.1 \pm 11.1$ & $43.0 \pm 18.9$ & $53.5 \pm 24.2$ & $0.001 *$ \\
\hline Physical functioning & $25.5 \pm 19.9$ & $41.9 \pm 19.9$ & $39.9 \pm 22.9$ & $51.1 \pm 8.9$ & $65.2 \pm 26.0$ & 0.001 * \\
\hline Physical role functioning & $0.0 \pm 0.0$ & $25.0 \pm 34.0$ & $2.8 \pm 8.1$ & $33.3 \pm 50.0$ & $44.3 \pm 45.6$ & 0.001 * \\
\hline Bodily pain & $29.3 \pm 16.3$ & $31.9 \pm 16.9$ & $33.2 \pm 17.0$ & $39.7 \pm 20.8$ & $55.5 \pm 21.6$ & $0.001 *$ \\
\hline General health & $34.8 \pm 20.3$ & $46.6 \pm 22.4$ & $49.4 \pm 18.1$ & $47.8 \pm 15.8$ & $48.9 \pm 20.1$ & $0.049 *$ \\
\hline
\end{tabular}

Table 3. Distribution of mean and standard deviation values of quality of life scores of the individuals according to their economic status

\begin{tabular}{|c|c|c|c|c|}
\hline \multirow{3}{*}{ SF-36 components } & \multicolumn{3}{|c|}{ Economic status } & \multirow{3}{*}{$p$ value } \\
\hline & \multirow{2}{*}{$\begin{array}{l}\operatorname{Low}(n=22) \\
(x \pm S D)\end{array}$} & \multirow{2}{*}{$\begin{array}{l}\text { Middle }(n=82) \\
(x \pm S D)\end{array}$} & \multirow{2}{*}{$\begin{array}{l}\text { High }(n=4) \\
(x \pm S D)\end{array}$} & \\
\hline & & & & \\
\hline Mental signs & $28.6 \pm 10.5$ & $37.9 \pm 20.5$ & $42.2 \pm 9.7$ & 0.150 \\
\hline Vitality & $34.3 \pm 12.0$ & $37.0 \pm 20.0$ & $52.5 \pm 8.7$ & 0.099 \\
\hline Social role functioning & $29.5 \pm 23.9$ & $43.1 \pm 26.4$ & $37.5 \pm 14.4$ & 0.076 \\
\hline Emotional role functioning & $6.1 \pm 13.2$ & $28.0 \pm 36.4$ & $16.7 \pm 19.2$ & $0.038^{*}$ \\
\hline Mental health & $44.5 \pm 18.3$ & $434 \pm 21.8$ & $62.0 \pm 25.4$ & 0.372 \\
\hline Physical signs & $25.1 \pm 11.4$ & $38.4 \pm 22.2$ & $33.4 \pm 9.7$ & $0.036^{*}$ \\
\hline Physical functioning & $30.5 \pm 17.3$ & $45.4 \pm 26.6$ & $42.5 \pm 2.9$ & $0.036^{\star}$ \\
\hline Physical role functioning & $2.3 \pm 7.4$ & $24.1 \pm 38.2$ & $0.0 \pm 0.0$ & $0.026^{\star}$ \\
\hline Bodily pain & $29.0 \pm 23.9$ & $38.0 \pm 20.7$ & $56.3 \pm 13.0$ & $0.015^{*}$ \\
\hline General health & $38.9 \pm 21.7$ & $46.2 \pm 20.2$ & $35.0 \pm 23.1$ & 0.202 \\
\hline
\end{tabular}


and their pain scores and physical dysfunction were higher $(14,15)$. Some authors concluded that the body weight was not related with the pain (16). Most patients with fibromyalgia (75$90 \%$ ) complain of non-deepening, non-restful sleep disorder. The presence of the alpha waves that should not normally be seen in delta wave sleep in the deepest phase of sleep in fibromyalgia patients causes sleep deprivation (17). Although sleep disorders are common in patients with FMS, the number of studies showing its relationship with the quality of life is limited (5). In the present study, while no significant correlation was found between the sleep pattern and the physical signs except for physical role functioning score, the difference between the vitality and mental health from mental signs and total mental sign scores was found to be significant. Physical role functioning score was found to be higher in those with regular sleep than the other individuals and this was statistically significant $(p<0.05)$. While mental health score was found to be high in individuals who had an irregular sleep at some nights; vitality score and mental sign score of the individuals who slept regularly were significantly high compared to the other groups $(p<0.0)$. In the study by Wagner et al., (18) the quality of life of patients with sleep disorder was found to be significantly lower than those without sleep disorder. Recent studies also suggest a multidisciplinary approaches including pharmacological treatment, psychotherapy, training programs, pain and fatigue control, sleep pattern improvement, mood control, and psychosocial reintegration in FMS treatment $(19,20)$.

\begin{tabular}{|c|c|c|c|c|c|}
\hline \multirow{3}{*}{ SF-36 components } & \multicolumn{4}{|c|}{ BMI classification } & \multirow{3}{*}{$p$ value } \\
\hline & \multirow{2}{*}{$\begin{array}{l}\begin{array}{l}\text { Underweight } \\
(n=2)\end{array} \\
(x \pm S D) \\
\end{array}$} & \multirow{2}{*}{$\begin{array}{l}\begin{array}{l}\text { Normal } \\
(n=40)\end{array} \\
(x \pm S D) \\
\end{array}$} & \multirow{2}{*}{\begin{tabular}{|l}
$\begin{array}{l}\text { Overweight } \\
(n=40)\end{array}$ \\
$(x \pm S D)$ \\
\end{tabular}} & \multirow{2}{*}{$\begin{array}{l}\begin{array}{l}\text { Obese } \\
(n=26)\end{array} \\
(x \pm S D)\end{array}$} & \\
\hline & & & & & \\
\hline Mental signs & $46.0 \pm 0.0$ & $36.3 \pm 19.9$ & $37.7 \pm 20.0$ & $32.8 \pm 16.2$ & 0.504 \\
\hline Vitality & $40.0 \pm 0.0$ & $40.2 \pm 19.5$ & $35.8 \pm 19.5$ & $33.8 \pm 15.4$ & 0.642 \\
\hline Social role functioning & $62.5 \pm 0.0$ & $35.6 \pm 26.6$ & $45.3 \pm 27.8$ & $37.5 \pm 21.1$ & 0.218 \\
\hline Emotional role functioning & $33.3 \pm 0.0$ & $25.0 \pm 37.6$ & $25.8 \pm 32.5$ & $15.4 \pm 30.2$ & 0.338 \\
\hline Mental health & $48.0 \pm 0.0$ & $44.3 \pm 20.6$ & $44.0 \pm 22.3$ & $44.5 \pm 22.5$ & 0.994 \\
\hline Physical signs & $36.9 \pm 0.0$ & $39.3 \pm 21.9$ & $37.9 \pm 23.7$ & $25.9 \pm 9.6$ & 0.121 \\
\hline Physical functioning & $45.0 \pm 0.0$ & $49.9 \pm 26.8$ & $38.6 \pm 27.9$ & $35.8 \pm 14.7$ & 0.050 \\
\hline Physical role functioning & $25.0 \pm 0.0$ & $20.6 \pm 37.9$ & $28.8 \pm 39.0$ & $0.0 \pm 0.0$ & $0.002^{*}$ \\
\hline Bodily pain & $32.5 \pm 0.0$ & $39.0 \pm 20.0$ & $38.9 \pm 23.0$ & $30.6 \pm 16.2$ & 0.399 \\
\hline General health & $45.0 \pm 0.0$ & $48.8 \pm 23.0$ & $45.4 \pm 18.7$ & $37.1 \pm 20.0$ & 0.186 \\
\hline
\end{tabular}

Table 5. Distribution of mean and standard deviation values of quality of life scores according to sleep pattern

\begin{tabular}{|c|c|c|c|c|}
\hline \multirow{3}{*}{ SF-36 components } & \multicolumn{3}{|c|}{ Sleep pattern } & \multirow{3}{*}{$p$ value } \\
\hline & \multirow{2}{*}{$\begin{array}{l}\begin{array}{l}\text { Regular } \\
(n=11)\end{array} \\
(x \pm S D)\end{array}$} & \multirow{2}{*}{$\begin{array}{l}\text { Some nights } \\
(n=14)\end{array}$} & \multirow{2}{*}{$\begin{array}{l}\text { Irregular } \\
(n=83)\end{array}$} & \\
\hline & & & & \\
\hline Mental signs & $46.6 \pm 23.5$ & $43.8 \pm 16.3$ & $33.5 \pm 18.0$ & $0.032^{*}$ \\
\hline Vitality & $55.0 \pm 22.2$ & $45.4 \pm 13.9$ & $33.2 \pm 16.8$ & $0.001^{*}$ \\
\hline Social role functioning & $36.4 \pm 23.4$ & $50.0 \pm 24.5$ & $39.0 \pm 26.4$ & 0.459 \\
\hline Emotional role functioning & $45.5 \pm 45.4$ & $19.0 \pm 36.3$ & $20.9 \pm 33.6$ & 0.177 \\
\hline Mental health & $49.5 \pm \mathbf{2 3 . 8}$ & $60.9 \pm \mathbf{1 3 . 4}$ & $40.8 \pm \mathbf{2 0 . 8}$ & $0.002^{*}$ \\
\hline Physical signs & $48.8 \pm 27.6$ & $33.1 \pm 17.4$ & $34.2 \pm 19.9$ & 0.315 \\
\hline Physical functioning & $47.7 \pm 27.6$ & $36.1 \pm \mathbf{2 5 . 4}$ & $42.5 \pm \mathbf{2 4 . 9}$ & 0.346 \\
\hline Physical role functioning & $54.5 \pm 52.2$ & $10.7 \pm 18.9$ & $15.4 \pm 31.4$ & $0.017^{*}$ \\
\hline Bodily pain & $42.7 \pm 19.3$ & $38.2 \pm \mathbf{2 3 . 0}$ & $35.8 \pm \mathbf{2 0 . 1}$ & 0.437 \\
\hline General health & $50.0 \pm 19.4$ & $47.5 \pm \mathbf{1 6 . 0}$ & $43.0 \pm \mathbf{2 1 . 6}$ & 0.352 \\
\hline
\end{tabular}




\section{Conclusion}

Consequently, it can be asserted that the quality of life was better in female patients diagnosed with fibromyalgia who had high educational and income levels, normal BMI, and a regular sleeping. In other words, female patients with these characteristics had a better quality of life. In general, studies have revealed that education, income status, BMI and sleep quality are important and remarkable concepts.

Further studies are needed with more groups of participants to extend the results of the present study and increase the value of evidence. Thus, we think that the life quality level of women with fibromyalgia, from which sociodemographic characteristics it is affected can be more easily determined and the exact results can be demonstrated.

\section{Ethics}

Ethics Committee Approval: The ethical approvals were taken from Bingöl University Scientific Research Publications Ethics Committee (dated: 09.05.2016 and numbered 29).

Informed Consent: All participants gave written and verbal permission to participate in this study.

Peer-review: Internally peer-reviewed.

\section{Authorship Contributions}

Surgical and Medical Practices: A.B., Concept: A.B., Design: A.B., Data Collection or Processing: E.T., Analysis or Interpretation: A.B., Literature Search: E.T., Writing: A.B.

Conflict of Interest: No conflict of interest was declared by the authors.

Financial Disclosure: The authors declared that this study received no financial support.

\section{References}

1. Gür A. Etiopathogenesis in Fibromyalgia. Turk J Phys Med Rehab 2008;54(Suppl 1):4-11.

2. Inanıcı F. Fibromyalgia and myofascial pain syndromes. Türkiye Klinikleri Journal of Physical Medicine and Rehabilitation 2005;10:11-8.

3. Bellato E, Marini E, Castoldi F, Barbasetti N, Mattei L, Bonasia DE, et al. Fibromyalgia syndrome: etiology, pathogenesis, diagnosis, and treatment. Pain Res Treat 2012;2012:426130.

4. Pagano T, Matsutani LA, Ferreira EA, Marques AP, Pereira CA. Assessment of anxiety and quality of life in fibromyalgia patients. Sao Paulo Med J 2004;122:252-8.
5. Wolfe F, Clauw DJ, Fitzcharles MA, Goldenberg DL, Katz RS, Mease P, et al. The American College of Rheumatology preliminary diagnostic criteria for fibromyalgia and measurement of symptom severity. Arthritis Care Res (Hoboken) 2010;62:60010.

6. "An excerpt from the User's Manual for the SF-36v2 Health Survey." 2nd ed. 2007. p. 29-37.

7. Kwok WY, Kloppenburg M, Beaart-van de Voorde LJ, Huizinga TW, Vliet Vlieland TP. Role of rheumatology clinical nurse specialists in optimizing management of hand osteoarthritis during daily practice in secondary care: an observational study. J Multidiscip Healthc 2011:4:403-11.

8. Ware JE Jr, Sherbourne CD. The MOS 36-item Short-Form HealthSurvey (SF-36). I. Conceptual framework and item selection. Med Care 1992;30:473-83.

9. Tot Ş, Toros $F$. The correlation of Fibromyalgia syndrome with psychiatric disorders. Anatolian Journal of Psychiatry 2002;3:232-9.

10. Taşkın EO, Tıkız C, Yüksel EG, Fırat A, Tüzün Ç, Aydemir Ö. Prevalence of depressive disorders among patients with fibromyalgia seeking help for the first time and its relationship with alexithymia. Anatolian Journal of Psychiatry 2007;8:248-55.

11. Yunus MB. Fibromyalgia syndrome: clinical features and spectrum. The Fibromyalgia Syndrome: Current Research and Future Directions in Epidemiology, Pathogenesis and Treatment. In: Pillemer R, editor. New York: The Haworth Medical Press Inc; 1994. p. 521.

12. Okifuji A, Donaldson GW, Barck L, Fine PG. Relationship between fibromyalgia and obesity in pain, function, mood, and sleep. J Pain 2010;11:1329-37.

13. Yunus MB, Arslan S, Aldag JC. Relationship between body mass index and fibromyalgia features. Scand J Rheumatol 2002;31:27-31.

14. Aparicio VA, Ortega FB, Heredia JM, Carbonell-Baeza A, DelgadoFernández M. Analysis of the body composition of Spanish women with fibromyalgia. Reumatol Clin 2011;7:7-12.

15. Kim CH, Luedtke CA, Vincent A, Thompson JM, Oh TH. Association of body mass index with symptom severity and quality of life in patients with fibromyalgia. Arthritis Care Res (Hoboken) 2012;64:222-8

16. Somers TJ, Keefe FJ, Pells JJ, Dixon KE, Waters SJ, Riordan PA, et al. Pain Catastrophizing And Pain- Related Fear İn Osteoarthritis Patients: Relationships To Painand Disability J Pain Symptom Manage 2009:37:863-72.

17. Anch AM, Lue FA, MacLean AW, Moldofsky H. Sleep physiology and psychological aspects of the fibrositis (fibromyalgia) syndrome. Can J Psychol 1991;45:179-84

18. Wagner JS, Dibonaventura MD, Chandran AB, Cappelleri JC. The association of sleep difficulties with health-related quality of life among patients with fibromyalgia. BMC Musculoskeletal Disord 2012;13:199.

19. Van Abbema R, Van Wilgen CP, Van Der Schans CP, Van Ittersum $\mathrm{MW}$. Patients with more severe symptoms benefit the most from an intensive multimodal programme in patients with fibromyalgia. Disabil Rehabil 2011;33:743-50.

20. Martins MR, Polvero LO, Rocha CE, Foss MH, Santos Junior RD. Using questionnaires to assess the quality of life and multidimensionality of fibromyalgia patients. Rev Bras Reumatol 2012;52:21-6. 